\title{
The Effect of Asset Structure and Firm Size on Firm Value with Capital Structure as Intervening Variable
}

\section{Setiadharma $\mathbf{S}$ and Machali $\mathbf{M}^{*}$}

Department of Accounting, Malangkuçeçwara College of Economics, Malang, Indonesia

\begin{abstract}
The purpose of this study is to analyse the direct and indirect effect of asset structure and firm size on the firm value. The samples of this study are thirty four property and real estate firms registered in Indonesia Stock Exchange in the period 2010-2014. The result of this study shows that (1) there is a direct effect of asset structure on the firm value, (2) there is no indirect effect of asset structure on the firm value with capital structure as intervening variable, (3) there is no direct effect of firm size on the firm value, (4) there is no indirect effect of firm size on the firm value with capital structure as intervening variable. Thus, it can be concluded thatcapital structure as intervening variable cannot mediate the relationship betweenasset structure and firm size on the firm value.
\end{abstract}

Keywords: Asset structure; Firm size; Capital structure; Firm value

\section{Introduction}

The trending investments nowadays are in the form of land, building, and property. This results in the fast growing of property and real estate industry. Land's price which increases by $25 \%$ each year also contributes in the growing of the firm industry. The firm value in this sector increases significantly in the past 5 years, which make the capital gain has increased by $187 \%$ as well. This enhancement is also the result of the increase in investor (share holder) who invests their money in the capital market. Firm value is a measurement of the upcoming firm's management success and it is able to increase the credibility of the firm towards the shareholder. If the needs of shareholders are fulfilled, it will have a good impact on the firm value. Considering the purpose of increasing the firm value, the firm needs to be cautious in making decision and considers the impact to the stock price. For management, the firm valueis an indicator for the investor about the past performance of the firm and the upcoming prospect of the firm. Brandenburger and Stuart [1] state that for the firm that has not gone public yet, firm value is the amount that will be paid by the buyer if the firm is sold. Meanwhile for the firm that has gonepublic, the firm value can be concluded from the stock price in capital market. The increase of stock price affects the firm value, which makes the shareholder gets more profit. When the stock price increases, the welfare of the shareholder increases as well. Saleh et al. [2] point out that there are some factors that affect the firm value, which are: asset structure, capital structure, firm size, firm growth, and investment decision.

A lot of studies examining the factors affecting firm value have been done previously. Firstly, firm value is affected by asset structure. Assets are property or property owned by the company in a certain period. Based on the way and duration, there are two types of assets: current asset and fixed asset. The ratio of those assets will determine the firm asset structure. The condition of the company's assets may affect the company's funding policy. Companies that have more current assets in their asset structure tend to use debt to meet their financing activities, while firms with more fixed assets tend to use their own capital to meet their financing activities. A firm that has suitable asset for collateral will get loan, which will make the firm getting the source of funds easily, which increases the firm value. The study done by Nyamasege et al. [3] show a result that asset structure affects positively significant on the firm value. This study is not consistent with that of Okwo et al. [4] which states that asset structure does not have any effect on firm value.
Secondly, firm value is affected by firm size. According to Brealey and Myers, a big firm has wide-spread stock, but it will make the stock less controlled/dominated from a certain party. On the other hand, stocks owned by a small firm are only distributed in a small area. A big firm tends to take a risk in selling their stock to maintain the needs of sales growth. Total of assets owned by a firm indicates the firm size. The bigger the firm size, the easier it is to get internal or external source of funds, which will affect the firm value itself. Previous studies which investigate the effect of firm size on firm value shows different results. Mule et al. [5] show that corporate size has no statistically significant impact on firm market value. The study done by Berger and Patti shows that firm size affects positively on firm value [6].

Thirdly, firm value is affected by capital structure. Funding plays an important role in a business. Setbacks are often caused by financial problems, which are caused by limited source of funds and rejection in applying a loan. Funding policy is an important matter that later will be used as indicator in determining the proportion between loan and equity. The first thing that has to be done by firm management is to increase firm value by carefully setting a capital structure. Before setting the capital structure, a firm has to understand fully the main components of capital structure. An optimum capital structure is the one which maximizes the stock price. Excessive loans may detain the firm development and make the share holder think twice before investing. A capital structure is a serious matter for a firm because the quality of capital structure may affect the firm's financial state and the firm value as well. Studies in testing the effect of capital structure on firm value have been done by Ogbulu and Emeni, Kausar et al. [7], Aggarwal and Padhan [8], Sumiati and Manihuruk [9], however, the results are inconsistent. Study done by Ogbulu and Emeni shows that long-term debt and equity as components of capital structure, Long-

*Corresponding author: Muslichah Machali, Department of Accounting Malangkucecwara College of Economics, Malang, Indonesia, Tel: +62341491813; E-mail: muslichahmachali@yahoo.com

Received September 19, 2017; Accepted October 27, 2017; Published November 07, 2017

Citation: Setiadharma S, Machali M (2017) The Effect of Asset Structure and Firm Size on Firm Value with Capital Structure as Intervening Variable. J Bus Fin Aff 6: 298. doi: 10.4172/2167-0234.1000298

Copyright: (C 2017 Setiadharma S, et al. This is an open-access article distributed under the terms of the Creative Commons Attribution License, which permits unrestricted use, distribution, and reproduction in any medium, provided the original author and source are credited. 
term-debt was found to be the major determinant of firm's value. It is different with the result of study done by Kausar et al. [7] which found that capital structure measured by long term debt to total assets and total debt to total assets has a significant negative impact on firm value. Result of Sumiati and Manihuruk [9] study show that capital structure did not have significant effect on firm value.

Based on the results of previous studies, direct effect of asset structure, capital structure and firm size on firm value did not show a consistent result. Furthermore, there has not been any study that reviews the indirect effect of asset structure and firm size on firm value using capital structure as intervening variable. According to Brigham and Houston [10], one of the factors that affects capital structure is asset structure. A firm in which the asset majority is from fixed asset will prioritize the source of funds through loan. A firm with a huge amount of fixed assets will have more loan because fixed assets can be used as collateral. Besides, firm size also affects firm capital structure because the bigger the firm size, the more they have loans. A big firm that has good reputation in the market is more likely to have loan as the source of funds. The bigger the loan is, the bigger the firm size is. A big firm size might reflect a better profit achievement in the future. Thus purpose of this study are twofold. First, to investigate the direct effect of asset structure and firm size on firm value. Second, to investigate the indirect effect of asset structure and firm size on firm value with capital structure as intervening variable.

\section{Hypothesis Development}

\section{The direct effect of asset structure on firm value}

Asset structure shows the amount of funds allocation in each part of assets. The allocation is important, because it is related to the amount of funds needed for the firm long-term's aim, which will determine the investors' perception towards the firm. Delcoure [11] shows a positive relation between asset structure with firm value. The firm will send a good signal to investors by adding fixed assets that may be used as collateral (signaling theory). According to Gaud et al. [12] liquidation value of fixed asset is usually higher than intangible asset, which means when a firm has gone bankrupt, it is less risky for the investors. Moreover, according to Alipour et al. [13], a large tangible asset will determine firm's capability in giving bigger collateral. Therefore, there is an effect of asset structure on firm value.

\section{H1: There is a direct effect of asset structure on firm value.}

\section{The indirect effect of asset structure on firm value with capital structure as intervening variable}

Gaud et al. [12] says that asset structure is a contributing factor on capital structure. The more tangible assets the firm owns, the more likely it can be used as collateral. A big tangible asset shows firm's capability to propose high collateral, and if any other factors are constant, the loan will be increased in order to get higher profit from the debtors. Frank and Goyal [14] state that the higher the tangible assets are pledged as collateral, the higher the leverage. The previous research show there is a positive relationship between asset structure and debt ratios [15-17].

Moreover, Pandey [18] argues that capital structure can affect the firm value. Therefore the purpose of the company should be directed at maximization of its value by examining its capital structure or financial leverage decision. The studies done by Vo and Ellis [19], Ogbulu and Emeni show that capital structure affects the firm value. It seems that the bigger the tangible assets are, the better they can show the firm's capability to give a bigger loan to increase the firm value.

$\mathrm{H} 2$ : There is an indirect effect of asset structure on firm value with capital structure as intervening variable.

\section{The direct effect of firm size on firm value}

Firm size is one of the variables that can affect firm value. A big firm size is an indicator of a good growth of the firm, this will give positive signal to investor, which leads to an increase in firm value. A big firm size reflects a better profit accomplishment in the future. A firm value is defined from its stock price. The result of the studies done by Berger and Patti show that the firm size affects firm value [6].

H3: There is a direct effect of firm size on firm value.

\section{The indirect effect of firm size on firm value with capital structure as intervening variable}

Brigham and Houston [10] say that firm size is a factor that affects capital structure because a big firm tends to have more loan. Firm size will affect the borrowing policy of a firm. A big firm that has good reputation in public will have more loan as the fund source. The aim is to optimize the firm value and minimalize the capital cost of firm. Study done by Karadeniz et al. [20] show that here is a statistically significant relationship between firm size and capital structure. Furthermore, A high firm value shows the welfare of the firm owner. An optimum capital structure might increase the firm value to the investor. Increasing borrowing might increase the firm value. A study done by Ogbulu and Emeni, Kausar et al. [7], Aggarwal and Padhan [8] and Sumiati and Manihuruk [9] show that capital structure affects firm value. In other words, a bigger firm size and a good reputation show the ability of a firm to get a loan, and it might increase the firm value to the investor.

H4: There is indirect effect of firm size on firm value with capital structure as intervening variable

Based on the arguments above, the model of this study can be seen in Figure 1.

\section{Research Methods}

\section{Population andsample}

According to the time of collection, this study uses Panel Data. Panel Data are a combination of series time data and cross section data. The

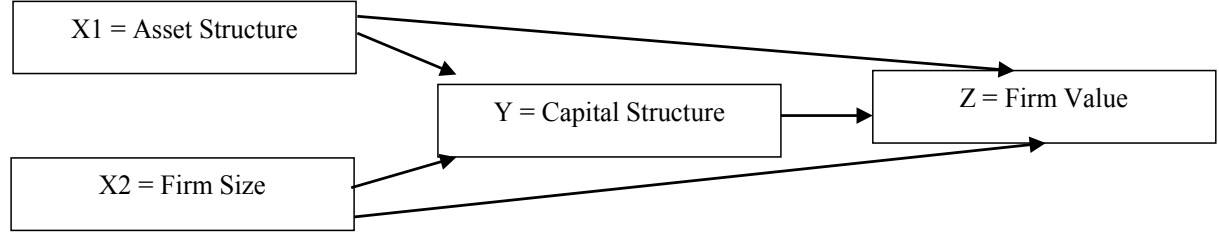

Figure 1: Model of the study 
Citation: Setiadharma S, Machali M (2017) The Effect of Asset Structure and Firm Size on Firm Value with Capital Structure as Intervening Variable. J Bus Fin Aff 6: 298. doi: 10.4172/2167-0234.1000298

Page 3 of 5

data source is the financial statement of the automotive industry firm and allied products, ICMD (Indonesian Capital Market Directory). The populations are all firms of property and real estate which are registered in Indonesia Stock Exchange. The sampling method used is purposive sampling. There are some criteria in choosing the population member to be sample of this study:

1. Firms of property and real estate which are registered in Indonesia Stock Exchange.

2. Have listed the financial statement of the firm in rupiah from the year 2010-2014.

Based on the criteria set, there are 34 qualified firms.

\section{Variables and measurement}

Firm value (Z): Firm value is the perception of investor in success rate of a firm which is often affiliated with the stock price. A high stock price creates a high firm value. A high firm value does not only show the credibility of the firm performance, but also the firm prospect in the future. The Proxy of firm value in this study is measured by price to book value (PBV).

$$
P B V=\frac{\text { Market Equity }}{\text { Book Equity }}
$$

Capital structure $(\mathrm{Y})$ : Capital structure is a combination of foreign capital and firm capital. The proxy of capital structure is measured by debt to equity ratio (DER). DER shows the ability of a firm to fulfill the total debt with the firm capital.

$$
D E R=\frac{\text { Amount of Debt }}{\text { Amount of Equity }}
$$

Asset structure (X1): Asset structure is the balance of current and fixed asset. Asset structure shows the collateral value of assets. The proxy of asset structure is measured by comparing the amount of the fixed assets and the total assets. Asset structure shows the amount of assets that can be used as collateral to the creditor. The formula of asset structure is:

$$
\text { Asset Structure }=\frac{\text { Amount of fixed assets }}{\text { Total assets }}
$$

Firm size (X2): Firm size can be stated in total of assets, sales, and market capitalization. The proxy of firm size is measured by book value of total assets. Because of the huge amount of firm assets' value, it is calculated in million rupiahs and is changed into natural logarithm (Ln). The formula of firm size is:

Firm Size $=$ Ln Total Assets.

\section{Analysis method}

Method of analysis used in this study is path analysis. There are two equations used in the method. The first equation shows the asset structure $\left(\mathrm{X}_{1}\right)$ and firm size $\left(\mathrm{X}_{2}\right)$ as the independent variables and capital structure $(\mathrm{Y})$ as dependent variable. The second regression equation treated firm value $(\mathrm{Z})$ dependent variable and firm size $\left(\mathrm{X}_{2}\right)$, asset structure $\left(\mathrm{X}_{1}\right)$ and capital structure $(\mathrm{Y})$ as the independent variables.

\section{The Results of Hypotheses Testing}

\section{Hypotheses testing}

Based on Tables 1 and 2 above, it can be concluded that:

1. The effect of capital structure on firm value:

According to t-test result in Table 2, the t-value is -0.116 with the $p$-value 0.907 , because the $p$ value $=0.907>0.05$. This shows that there is no significant effect of capital structure on firm value.

2. The effect of asset structure on firm value:

According to the $\mathrm{t}$-test result in Table 2, the $\mathrm{t}$-value is -3.054 with the $p$-value 0.003 , because the $p$ value $=0.003<0.05$. This shows that there is a significant effect of asset structure on firm value.

3. The effect of firm size on firm value:

According to the t-test result in Table 2, the t-value is 1.590 with the $\mathrm{p}$-value 0.114 , because the $\mathrm{p}$ value $=0.114>0.05$. This shows that there is no significant effect of firm size on firm value.

4. The effect of asset structure on capital structure:

According to the t-test result in Table 1 , the $\mathrm{t}$-value is 0.036 with the $p$-value 0.972 , because the $p$ value $=0.972>0.05$. This shows that there is no significant effect of asset structure on capital structure.

5. The effect of firm size on capital structure

According to the t-test result in Table 2, the t-value is 5.143 with

\begin{tabular}{|c|c|c|c|c|c|c|}
\hline \multirow[t]{2}{*}{ Model } & \multicolumn{2}{|c|}{ Unstandardized Coefficients } & \multirow{2}{*}{$\begin{array}{c}\text { Standardized } \\
\text { Coefficients } \\
\text { Beta }\end{array}$} & \multirow[t]{2}{*}{$\mathbf{T}$} & \multirow[t]{2}{*}{ Sig } & \multirow[t]{2}{*}{ Notes } \\
\hline & B & Std Error & & & & \\
\hline (Constant) & -0.736 & 0.174 & & & & \\
\hline Asset Structure & 0.003 & 0.094 & .002 & 0.036 & 0.972 & Insignificant \\
\hline Firm Size & 0.060 & 0.012 & .233 & 5.143 & 0.000 & Significant \\
\hline
\end{tabular}
the $\mathrm{p}$-value 0.000 , because the $\mathrm{p}$ value $=0.000<0.05$. This shows that there is a significant effect of firm size on capital structure.

\begin{tabular}{|c|c|c|c|c|c|c|}
\hline \multirow[t]{2}{*}{ Model } & \multicolumn{2}{|c|}{ Unstandardized Coefficients } & \multirow{2}{*}{$\begin{array}{c}\text { Standardized } \\
\text { Coefficients } \\
\text { Beta }\end{array}$} & \multirow[t]{2}{*}{$\mathbf{T}$} & \multirow[t]{2}{*}{ Sig } & \multirow[t]{2}{*}{ Notes } \\
\hline & B & Std Error & & & & \\
\hline (Constant) & 0.033 & .387 & .033 & & & \\
\hline Asset Structure & -0.652 & .213 & -.652 & -3.054 & 0.003 & Significant \\
\hline Firm Size & 0.043 & .027 & .043 & 1.590 & 0.114 & Insignificant \\
\hline Capital Structure & -0.009 & .077 & -.009 & -0.116 & 0.907 & Insignificant \\
\hline
\end{tabular}

Source: Secondary data that has been processed.

Table 1: Regression result of the effect of asset structure and firm size on capital structure.

Source: Secondary data that has been processed.

Table 2: Regression result-The effect of asset structure, firm size, and capital structure on firm value. 


\begin{tabular}{|l|l|c|}
\hline \multicolumn{2}{|c|}{ Hypothesis } & Notes \\
\hline H1 & Direct effect of asset structure on firm value & Hypothesis is accepted \\
\hline H2 & Indirect effect of asset structure on firm value with capital structure as intervening variable & Hypothesis is rejected \\
\hline H3 & Direct effect of firm size on firm value & Hypothesis is rejected \\
\hline H4 & Indirect effect of firm size on firm value with capital structure as intervening variable & Hypothesis is rejected \\
\hline
\end{tabular}

Source: Secondary data that has been processed.

Table 3: The result of hypothesis test.

According to the result of regression presented in Tabels 1 and 2, the result of hypotheses testing is as follows:

The first hypothesis states that there is a direct effect of asset structure on firm value. The result of path analysis test in Table 2 shows that asset structure affects negatively significant on firm value, so the hypothesis is accepted. Property and real estate firm has characteristic of land's usage as its fixed asset. In financial accounting standard 16 about Fixed Asset, it is stated that the land which is owned in a long term and is not to be put on sale in a short-term is considered as a fixed asset. When the land is sold to other party, it is not considered as a fixed asset anymore, but as a trading current asset. This is considered as a good thing to the investors, because they expect that the stock price and firm value will be increased by the profit return of the asset selling.

The second hypothesis states that there is an indirect effect of asset structure on firm value. The result of path analysis test in Table 1 shows that asset structure does not have significant effect on firm value, so it can be concluded that there is no indirect effect of asset structure on firm value, which means the hypothesis is rejected.

The third hypothesis states that there is a direct effect of firm size on firm value. The result of path analysis test in Table 2 shows that firm size does not have significant effect on firm value, so the hypothesis is rejected. A big asset value of a firm does not guarantee that investor's impression towards the firm will increase.

The fourth hypothesis states that there is an indirect effect of a firm size on firm value. The result of path analysis test in Table 1 shows that firm size has significant effect on capital structure and the result of path analysis test in Table 2 shows that capital structure does not have a significant effect on firm value, so it can be concluded that there is no indirect effect of firm size on firm value, and the hypothesis is rejected (Table 3).

Therefore it is concluded that capital structure as intervening variable does not affect and is not able to mediate the variable effect of asset structure and firm size on firm value. Firm capital structure policy and firm effort to optimize capital structure cannot increase the stock price/firm value and does not affect the investor's impression.

\section{Discussion}

There are two reasons of why there is no effect of firm size and capital structure on firm value. Firstly, because investors in Indonesia do not consider accounting information and do not think of capital structure and firm size as a base of investment decision. Ady et al. [21] in his study about investor behavior in capital market in Indonesia finds that investors in Indonesia are more likely to be irrational in investing, in which the investor sells high-priced stock recklessly and holds low-priced stock too long. These irrational investors in Indonesia cannot process and intepret the information well. A rational investor will analyze before investment decision making and read up firm's financial statement, and evaluate the firm's business performance. In the study done by Ismawati and Haryono [22], it is partially stated that fundamental factor and systematic risk that are considered by the investor in this industry is just the profitability which is measured by Return on Asset (ROA), meanwhile the other factors such as liquidity, solvability, and market ratio do not have any big impact in stock buying decision.

The second reason why there is no effect of firm size and capital structure on firm value is related to firm dividend policy. In the study done by Nwamaka and Ezeabasili [23] show that dividend policy affects positively significant on firm value. The firms with big assets and firms that have loans as the source of funds do not always share the profit to the shareholder. The firms do not always share the dividend to retain the profit as capital, this is related to the firm dividend policy. Firm which retains the profit rather than share it as dividend might affect the stock price and its firm value. Firm dividend policy is another factor that might affect stock price/firm value.

\section{Conclusion and Implication for Further Study}

The purpose of this study is to see the direct and indirect effect of asset structure and firm size on the firm value. According to the result of the study and discussion, the conclusion of this study are:

1. There is a direct effect of asset structure on the firm value of firms of property and real estate which are registered in Indonesia Stock Exchange period 2010-2014.

2. There is no indirect effect of asset structure on the firm value of firms of pproperty and real estate which are registered in Indonesia Stock Exchange period 2010-2014.

3. There is no direct effect of firm size on the firm value of firms of property and real estate which are registered in Indonesia Stock Exchange period 2010-2014.

4. There is no indirect effect of firm size on the firm value of firms of property and real estate which are registered in Indonesia Stock Exchange period 2010-2014.

5. Capital structure as intervening variable doesn't have any effect on the firm value and cannot mediate the variable of asset structure and firm size on the firm value of firms of property and real estate which are registered in Indonesia Stock Exchange period 20102014.

The result of this study can be used for the reference of the next researcher, and the next researcher can improve the study by investigating firms of other sectors and by using other variables that can affect the firm value. It is better to use Tobin's $Q$ for the proxy of firm value because it shows more of the firm condition. PBV Proxy (price book value) in this study cannot show the real state of firm value. Tobin's $\mathrm{Q}$ explains that firm value is a combination between the tangible asset and the intangible asset. If this study is going to be developed, it is better to add some aspects that can affect the firm value, such as profitability, dividend policy, liquidity, growth rate, and the borrowing policy of the firm. 
Citation: Setiadharma S, Machali M (2017) The Effect of Asset Structure and Firm Size on Firm Value with Capital Structure as Intervening Variable. J Bus Fin Aff 6: 298. doi: 10.4172/2167-0234.1000298

Page 5 of 5

\section{References}

1. Brandenburger A, Stuart JHW (1996) Value-Based Business Strategy. The Journal of Economics and Management Strategy 5: 5-24.

2. Saleh H, Priyawan S, Ratnawati T (2015) Influence of Assets Structure, Capital Structure and Market Risk on the Growth, Profitability and Corporate Values (Study in Manufacturing Companies Listed in Indonesia Stock Exchange). International Journal of Business and Management Invention 4: 45-53.

3. Nyamasege D, Okibo WBA, Nyang'au AS, Sang'ania PO, Omosa H, et al (2014) Effect of Asset Structure on Value of a Firm: A Case of Companies Listed in Nairobi Securities Exchange. Research Journal of Finance and Accounting 5: 205-212.

4. Okwo IM, Okelue UD, Nweze AU (2012) Investment in fixed assets and firm profitability: Evidence from the Nigerian brewery industry. European Journal of Business and Management 4: 10-17.

5. Mule RK, Mukras MS, Nzioka OM (2015) Corporate size, profitability and market value: An econometric panel analysis of listed firms in Kenya. European Scientific Journal 11: 376-396.

6. Berger AN, Bonaccorsi di Patti E (2006) Capital structure and firm performance: A new approach to testing pecking order theory and an application to banking industry. Journal of Banking and Finance 30: 1065-1102.

7. Kausar A, Nazir MS, Butt HA (2014) Capital Structure and Firm Value: Empirical Evidence from Pakistan. Asian Journal of Research in Economics and Finance 1: 11-22.

8. Aggarwal D, Padhan PC (2017) Impact of Capital Structure on Firm Value: Evidence from Indian Hospitality Industry. Theoretical Economics Letters 7 982-1000.

9. Sumiati D, Manihuruk W (2016) Determinants of Capital Structure and the Role of Capital Structure on Firm Value Wiston. European Journal of Business and Management 8: 182-194.

10. Brigham EF, dan Houston JF (2011) Fundamental of Financial Management. ( $11^{\text {th }}$ edition), Cengage Learning.

11. Delcoure N (2006) The Determinants of Capital Structure in Transitional Economies. International Review of Economic and Finance.
12. Gaud P, Jani E, Hoesli M, Bender A (2003) The Capital Structure of Swiss Companies: An Empirical Analysis Using Dynamic Panel Data. European Financial Management.

13. Alipour M, Mohammadi MFS, Derakhshan H (2015) Determinants of capital structure: An empirical study of firms in Iran. International Journal of Law and Management 57: 53-83.

14. Frank MZ, Goyal VK (2003) Capital Structure Decisions. AFA San Diego Meetings.

15. Chiang YH, Cheng EWL, Lam PTI (2010) Epistemology of capital structure decisions by building contractors in Hong Kong. Construction Innovation 10 329-345.

16. Deloof M, Overfelt WV (2008) Were modern capital structure theories valid in Belgium before world war I? Journal of Business Finance \& Accounting 35: 491-515.

17. Frank MZ, Goyal VK (2002) Testing the pecking order theory of capital structure Journal of Financial Economics 67: 217-248.

18. Pandey IM, Chotigeat T (2004) Theories of Capital Structure: Evidence from an Emerging Market. Studies in Economics and Finance 22: 1-19.

19. Vo XV, Ellis C (2017) An empirical investigation of capital structure and firm value in Vietnam. Finance Research Letters 22: 90-94.

20. Karadeniz E, Serkan Y, Iskenderoglu O (2011) Firm Size and Capital Structure Decisions: Evidence from Turkish Lodging Companies. International Journal of Economics and Financial Issues 1: 1-11.

21. Ady SU, Sudarma M, Salim U, Aisyah S (2013) Psychology's Factors of Stock Buying and Selling Behavior in Indonesia Stock Exchange (Phenomenology Study of Investor Behavior in Surabaya). Journal of Business and Management 7: 11-22.

22. Ismawati I, Haryono T (2007) Micro and Macro Fundamental Factors, Systematic Risk and Stock Performance after Global Crisis. International Journal of Business and Commerce 6: 55-69.

23. Nwamaka OC, Ezeabasili (2017) Effect of Dividend Policies on Firm Value: Evidence from quoted firms in Nigeria. International Journal of Management Excellence 8: 956-967. 